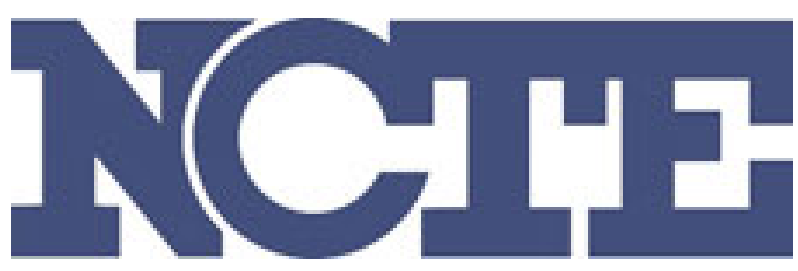

The Power to Speak and Listen: Democratic Pedagogies for American Literature Classrooms Author(s): Robert Petrone and Robert Gibney

Source: The English Journal, Vol. 94, No. 5 (May, 2005), pp. 35-39

Published by: National Council of Teachers of English

Stable URL: http://www.jstor.org/stable/30047351

Accessed: 09/02/2015 14:43

Your use of the JSTOR archive indicates your acceptance of the Terms \& Conditions of Use, available at

http://www.jstor.org/page/info/about/policies/terms.jsp

JSTOR is a not-for-profit service that helps scholars, researchers, and students discover, use, and build upon a wide range of content in a trusted digital archive. We use information technology and tools to increase productivity and facilitate new forms of scholarship. For more information about JSTOR, please contact support@ jstor.org. 


\section{The Power to Speak and Listen: Democratic Pedagogies for American Literature Classrooms}

The authors advocate teaching high school students to investigate and transform their worlds. Robert Petrone and Robert Gibney describe two American literature units in which they helped

A students develop the necessary "critical habits of mind, skills, and dispositions."

s my tenth graders shuffled into the classroom on the first day of school, I (Robert Petrone) handed each of them a one dollar bill. After the initial excitement of being given a dollar subsided and they settled down, I asked them to note what they observed on either side of the bill. After briefly reviewing what they had observed (George Washing-

The world is filled with people who are no longer needed

And who try to make slaves of all of us

And they have their music and we have ours

Theirs, the wasted songs of a superstitious nightmare

And without their musical and ideological miscarriages

to compare our songs of freedom to,

We'd not have any opposite to compare music with

And like the drifting wind, hitting against no obstacle,

We'd never know its speed, its power —Woody Gutbrie

English professors should be pressed to explain why the poetry sung by striking coal miners in the 1920's is so much less important than the appearance of ["The Waste Land"] in The Dial in 1922.

- Cary Nelson, Repression and Recovery ton, a bald eagle, a pyramid, an eye, the bill's green coloring, and so on), I then asked questions about their observations and encouraged them to begin asking questions as well. As a class, we asked the following questions: Why are those things on our country's dollar bill? Why does the bald eagle hold thirteen arrows in one talon and a laurel leaf with thirteen leaves in the other? And why is the eagle looking toward the laurel leaf? Why is there a pyramid? Why include the phrases Novus Ordo Seclorum and Annuit Coeptis? What do they mean? Why "In God We Trust"? We speculated about the significance of these images and phrases, how these things ended up on our country's dollar bill, and what the value was in even asking these types of questions. We then read a section of Joseph Campbell's The Power of Myth, in which he discusses the symbolic nature of the various im-

Additionally, this lesson began the process of pushing the students to see those cultural and social "objects" that appeared to be natural, fixed, and impenetrable as products of historical, socially constructed processes from which certain people benefited by having them be the way they are. ages and phrases of America's dollar bill. And thus began tenth-grade American literature. (And, yes, I did get my money back from the students!)

This lesson accomplished several objectives. First, by examining a dollar bill, a part of our country's everyday life, the lesson pushed students to begin the process of examining their visible American culture and society-even the most mundane

The world is filled with people . . . by Woody Guthrie (C) 1998 by WOODY GUTHRIE PUBLICATIONS, INC. All rights reserved. Used by permission. 
and familiar aspects-in ways they had not done previously. It asked them to observe and then question what they observed. Inevitably, as was demonstrated throughout the year, the process of calling into question what they observed also forced them to consider the less-visible aspects of our society and culturewhat they were not observing (What was missing?) and what they could be observing (What is possible?). Additionally, this lesson began the process of pushing the students to see those cultural and social "objects" that appeared to be natural, fixed, and impenetrable as products of historical, socially constructed processes from which certain people benefited by having them be the way they are.

Drawing from the work of critical-literacy theorists (Freire; Giroux), American literary scholars (Denning; Nelson), and the work of scholars interested in secondary literature pedagogy (Applebee), we posit an approach to the teaching of American literature in secondary schools that foregrounds issues of power, marginalization, representation, popular culture, canon formation, and democracy rather than the usual issues of personal response (reader response) and aesthetics (New Criticism). While reader response and New Criticism remain important components of our pedagogy, we strive to foreground historical, cultural, and social issues. Our approach creates spaces for students to investigate and actively engage with the traditions and texts they are oftentimes merely required to "study" and "appreciate." We ask students to seek out the history, value, and functions of texts so they begin to see themselves not just as passive consumers of a tradition but as active, critical thinkers developing the skills, dispositions, and habits of mind to question those traditions they are so often meant to take at face value, traditions that privilege certain voices over others. As Henry A. Giroux argues,

Curriculum does not merely offer courses and skills, it functions to name and privilege particular histories and experiences. In its dominant form, it does so in such a way as to marginalize or silence the voices of subordinate groups. For critical educators, then, the English curriculum has to be seen as a site of struggle. The issue here is how can teachers of English educate students to be critical, rather than good, citizens. The distinction is central for educating students either to adapt to existing relations of power or to learn how to read society differently so as to apply the principles of a critical democracy to the creation of new and radical forms of community. In this case, the teaching of English must be seen as a form of citizenship education that seeks to expand, rather than restrict, the possibilities of democratic public life. (306)

Using American literature, then, as the forum for the development of critical habits of mind, skills, and dispositions, our experience is that students move beyond a description of their communal, institutional, and social worlds into an investigation and transformation of them. By critical we mean the development of consumptive, productive, and distributive literacy skills designed to help students describe, challenge, and transform existing conditions of their world as they develop traditional literacy skills of reading, writing, viewing, listening, and speaking. As Paulo Freire has written, fostering critical literacy helps students read the "word and the world." The remainder of this article, then, demonstrates how we implement this approach to the study of American literature with secondary students by highlighting two units of study.

\section{Behind the Veil: American Literature and Culture of the 1950s}

While teaching an American Authors class to high school juniors and seniors, I (Robert Petrone) divided the course content into four units of study. One unit, called Behind the Veil, focused attention on nonmainstream and marginalized voices, texts, experiences, and stories, particularly related to $1950 \mathrm{~s}$ American culture and literature. As the central text of the unit, I used August Wilson's play Fences, the story of "over the hill" Negro League slugger Troy Maxson set in 1957 Pittsburgh, Pennsylvania. Although written in the 1990s, Wilson's play attempts to encapsulate the experience of the African American community during the 1950s. Lorraine Hansberry's play A Raisin in the Sun would also be an excellent central text for this unit, especially since it was written and first performed during the 1950s.

To prepare students for a critical reading of Fences, we explored the culture, history, and society of America during the 1950s. I first asked the students to develop a collective 1950 s cultural memory by drawing on their own ideas and then asking their parents, grandparents, and other relatives about the culture and society of the time. Invariably, students came back to class discussion with images of poodle 
skirts, Chevys, greasers, Leave it to Beaver, Elvis Presley, I Like Ike, and a general sense of the 1950s as the "good ol' happy days."

Once we established this sense of the 1950s, I asked them to describe the 1960s. Within minutes we generated as long a list as that of the 1950s: hippies, Woodstock, the civil rights movement, the Vietnam War, the assassinations of JFK and MLK, riots, protests, and an overall sense of unrest and rebellion. Juxtaposing the images of the 1950s and 1960s, I asked them how a country goes from the happy days of the 1950s to the sex, drugs, rock ' $n$ ' roll, war, and violence of the 1960s. And so began our investigation of the literature and culture of 1950 s America and our unit of study. One of the first questions we discussed was, Who and what is missing from or "behind" the picture of the 1950s we have created?

Throughout our investigation, the class uncovered many issues, concerns, texts, events, and people they had never heard of or studied critically or in depth. Three central issues surfaced for the students regarding what was behind the veil of their 1950s cultural portrait: race relations, such as the Montgomery bus boycott and the lynching of Emmett Till; international relations, such as the cold war and the Korean War, Communism, and the Red Scare; and an overall sense of unrest and discontent with mainstream American society, such as the attitudes evidenced by the Beatniks. Although this unit primarily focused on race relations, we did read, analyze, discuss, and investigate the other two issues. Specifically, we discussed J. D. Salinger's The Catcher in the Rye (a novel they had read during their sophomore year) as it related to the cold war and general sense of anxiety in the nation at the time. We read some of the poetry and prose of the Beat and other writers-Allen Ginsberg's "Howl," excerpts from Jack Kerouac's On the Road, and a chapter from Kurt Vonnegut's dystopian novel, Player Piano. We discussed some of the films of the time, such as $O n$ the Waterfront and The Man in the Gray Flannel Suit, as well as historical events such as Sputnik and the House Un-American Activities Committee hearings. The brief investigation of these aspects of American culture of the 1950s helped the students better understand not only issues from their previous unit of study - which focused on 1930s culture and literature-but also their subsequent unit of study (the literature and culture of the 1960s), a unit that high- lighted Ken Kesey's One Flew Over the Cuckoo's Nest, Vonnegut's Cat's Cradle, and the film Cool Hand Luke, especially as we discussed issues of conformity, iconoclasm, patriotism, and democracy.

The majority of the 1950s unit, though, was spent examining issues pertaining to race relations in the United States. In the midst of reading and discussing Wilson's play, the class read, viewed, and discussed the following supplementary texts:

$>$ "Shadow Ball," an episode of Ken Burns's Baseball documentary that explores the Negro Baseball Leagues

$>$ "When a Negro Moves Next Door," a Saturday Evening Post article from the 1950s (Rosen)

$>$ "Awakenings," the first episode of the Eyes on the Prize documentary on the civil rights movement; this episode focuses on events from the 1950s

> “'Past as Prologue': The 1950s as an Introduction to the 1960s," an essay about key historical events, people, and texts of the 1950 s (Bloom and Breines)

While the unit consisted of a variety of activities and assignments-including a guest speaker, an African American man who worked at the school and grew up in the Midwest during the 1950s-the culminating activity was the viewing of the film Smoke Signals and an analysis of what is "behind the veil" of today's American society. Students were able to use their critical examination of 1950 s culture and literature as a springboard for observation, investigation, and possible transformation of their present living situations.

\section{The Visible and the Invisible: Literary and Cultural Representations of the Native American}

In conjunction with our goal of fostering an English curriculum that acts as a "site of struggle," I (Robert Gibney) designed a Native American literature unit that begins with a critical examination of the visibility of Native Americans in popular culture. The Visible lesson begins with a small group of images presented to the class as evidence of the prominence of Native representation in popular culture. Students have likely been exposed to many of these images but may never have stopped to consider them 
And I, to whom so great a vision was given in my youth,- - you see me now a pitiful old man who has done nothing, for the nation's hoop is broken and scattered. There is no center any longer, and the sacred tree is dead.

$$
\text { -Nicholas Black Elk, }
$$

Black Elk Speaks: Being the Life Story of a Holy Man of the Oglala Sioux

critically. The Washington Redskins, the Jeep Cherokee, the Dodge Dakota, and Natural American Spirit cigarettes offer great places to start. I then ask students to brainstorm more images or products that rely on a particularly Native theme. Once we have developed a comprehensive list of images, students are asked to posit some assumptions about what an "Indian" is, based solely on how they are represented by the images we've listed. Some of the responses we have generated include the following:

$>$ Indians are noble but defeated. (The "Crying Indian" TV commercial from the 1970s)

$>$ Indians are violent and warlike. (Tomahawk missile, Apache attack helicopter)

$>$ Indians are drunks and illiterates. (Cleveland Indians mascot, Big Chief writing tabletproduction of these ended in 2001 but many students can still fondly recall scrawling their first alphabet on one)

$>$ Indians are in touch with a purity of nature and spirit that, like the Indians themselves, has vanished. (Pocahontas Foods, Land O'Lakes, Natural American Spirit)

The Invisible portion of the unit includes an assignment in which students choose one logo or product that relies on a stereotypical Native representation and critically examine its origins, asking questions such as, Who developed this representation? Why? Who benefits from it? How might it work to reinforce or disrupt mainstream dispositions toward Native Americans? This activity might also involve researching the origins of various terms, such as redskin, asking, for instance, how this noun describing a Native American has become synonymous with an athletic organization. The assignment is not necessarily designed to condemn or condone the appropriateness of the chosen image but to describe and problematize its role as both marketing tool and identity marker.

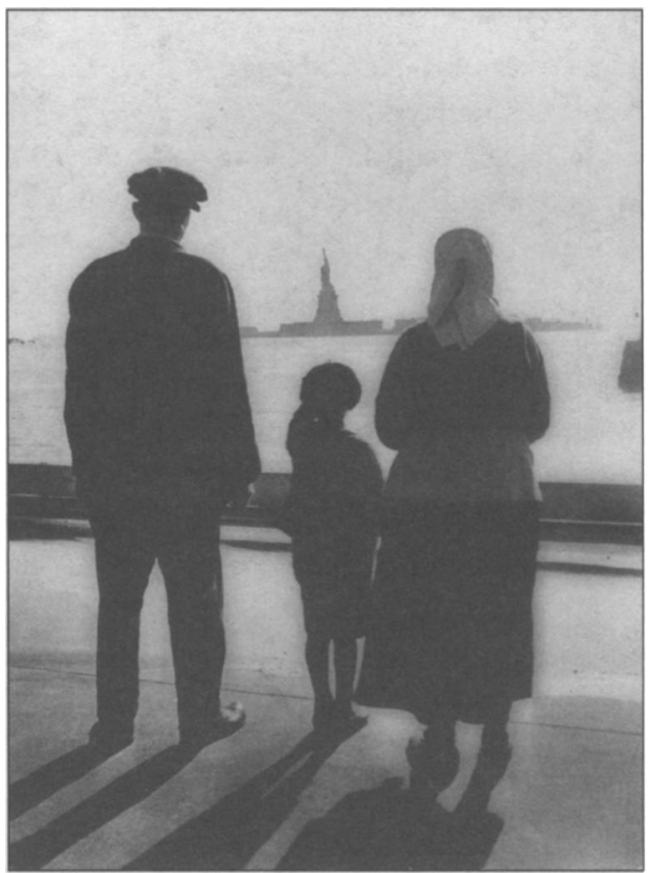

Library of Congress, Prints and Photographs Division, LC-USZ62-50904

Moving from popular culture images to literary ones, readings in this unit include selections from Black Elk Speaks, by John G. Neihardt, and from $N a$ tive American Literature: An Antbology, edited by Lawana Trout. Black Elk Speaks is a useful text to continue inquiry into the cultural invisibility of Native identity. We read this text in much the same way that the students "read" the image they chose in the initial activity. We ask questions such as, Who is the main character in Black Elk Speaks? Yes, it is the story of Black Elk, his Great Vision, and the fate of the Lakota people, but to what extent is this also the story of Neihardt, the actual writer of the text? Questioning Neihardt's role in telling Black Elk's story may lead students to question who, if anyone, is trusted to "tell" their story. We explore how we are defined by the television shows we watch, by the advertisements we are exposed to, or by other social-, cultural-, and gender-related expectations.

Lawana Trout's anthology is an accessible source for students to study the works of contemporary Native authors. We draw attention to the ways in which selected authors reject "visible" representations endorsed by ideologies still wound tightly in the myths of manifest destiny and noble savagery. N. Scott Momaday, Linda Hogan, Leslie Marmon Silko, and 
many others claim autonomous identities in the face of racism and stereotypes and call for the reader to do the same. Hogan, for instance, describes writing as an act of resistance in "The Two Lives." She insists that writing is the most powerful tool in the formation of an individual identity. "My own efforts," she writes, "have gone into new tools, the dismantling, the rebuilding. Writing is my primary crowbar, saw, and hammer. It is a way of not allowing ourselves to be depowered by disappearance" (36). Throughout the Trout readings, class discussion continually returns to issues of disappearance: Has Neihardt's text actually contributed to Black Elk's disappearance? Are you in any danger of disappearing due to the ways in which you've been represented?

Class discussions originate from popular culture representations of Native Americans, move on to examine Native American literary representations, and ultimately ask students to consider their identities as either the manifestation of accepted stereotypes or as autonomously created. This unit demonstrates how the English curriculum can become a space for students to observe, describe, investigate, and possibly transform their world and their relationship to it. Students are challenged to deepen their traditional literacy skills, such as literary analysis, reading, writing, and researching, pushing them to become not only active and critical but also skilled consumers, producers, and distributors of texts and information. Much like the end of the unit on 1950s culture and literature, this one concludes by asking students to consider how the stereotypical Native American images have been created, why might they have been created, who might benefit from their creation, and how the students might work to transform the images.

\section{Possibilities}

Although different in content, these outlined approaches to teaching American literature reveal a shared pedagogy designed to challenge and call into question long-held assumptions about the American literary tradition, cultural history, literary teaching practices, and contemporary American society. At the core of this pedagogy is the hope that the English classroom will expand rather than restrict spaces for the multiplicity of voices that define democracy. Finally, as is the goal of all such critical pedagogies, students are left with possibilities for critical The assignment is not necessarily designed to condemn or condone the appropriateness of the chosen image but to describe and problematize its role as both marketing tool and identity marker. action and active reflection. Our aim is to create opportunities for democratic transformation for our students, their communities, and the world.

\section{Works Cited}

Applebee, Arthur N. Curriculum as Conversation: Transforming Traditions of Teaching and Learning. Chicago: U of Chicago P, 1996.

Baseball. Dir. Ken Burns. PBS, 1994.

Bloom, Alexander, and Wini Breines. "'Past as Prologue': The 1950s as an Introduction to the 1960s." "Takin' It to the Streets": A Sixties Reader. Ed. Alexander Bloom and Wini Breines. New York: Oxford UP, 1995. 3-16.

Campbell, Joseph, with Bill Moyers. The Power of Myth. New York: Anchor, 1988.

Denning, Michael. The Cultural Front: The Laboring of American Culture in the Twentieth Century. New York: Verso, 1996.

Eyes on the Prize. Dir. Henry Hampton. PBS, 1987.

Freire, Paulo. Pedagogy of the Oppressed. Trans. Myra Bergman Ramos. New York: Continuum, 1970.

Giroux, Henry A. "Textual Authority and the Role of Teachers as Public Intellectuals." Social Issues in the English Classroom. Ed. C. Mark Hurlbert and Samuel Totten. Urbana: NCTE, 1992. 304-21.

Hogan, Linda. "The Two Lives." Native American Literature: An Antbology. Ed. Lawana Trout. Chicago: NTC, 1999. 26-41.

Neihardt, John G. Black Elk Speaks: Being the Life Story of a Holy Man of the Oglala Sioux. 1932. Lincoln: Bison, 2000.

Nelson, Cary. Repression and Recovery: Modern American Poetry and the Politics of Cultural Memory, 1910-1945. Madison: U of Wisconsin P, 1989.

Rosen, Ellsworth E. "When a Negro Moves Next Door." Saturday Evening Post 4 Apr. 1959: 32-33.

Trout, Lawana, ed. Native American Literature: An Antbology. Chicago: NTC, 1999.

Robert Petrone is currently pursuing his PhD in English education at Michigan State University. His interests include critical literacy, teaching English for social action, and the teaching of literature. email: petroner@msu.edu. Robert Gibney is pursuing a PhD in twentieth-century American literature at the University of Nebraska-Lincoln, where he teaches courses in Native American literature, writing, and composition. He received his master's degree in American literature from Northern Arizona University in Flagstaff. email: rgibney2@unlnotes.unl.edu. 